\title{
Chemical and Microbiological Hazards of Dried Fishes in Bangladesh: A Food Safety Concern
}

\author{
Md. Golam Rasul' ${ }^{1}$ Chunhong Yuan², A. K. M. Azad Shah ${ }^{1 *}$ \\ ${ }^{1}$ Department of Fisheries Technology, Faculty of Fisheries, Bangabandhu Sheikh Mujibur Rahman Agricultural University, \\ Gazipur, Bangladesh \\ ${ }^{2}$ Department of Food Production and Environmental Management, Faculty of Agriculture, Iwate University, Morioka, Japan \\ Email: ^azad@bsmrau.edu.bd
}

How to cite this paper: Rasul, Md.G., Yuan, C.H. and Shah, A.K.M.A. (2020) Chemical and Microbiological Hazards of Dried Fishes in Bangladesh: A Food Safety Concern. Food and Nutrition Sciences, 11, 523-539. https://doi.org/10.4236/fns.2020.116037

Received: April 24, 2020

Accepted: June 10, 2020

Published: June 17, 2020

Copyright (c) 2020 by author(s) and Scientific Research Publishing Inc. This work is licensed under the Creative Commons Attribution International License (CC BY 4.0).

http://creativecommons.org/licenses/by/4.0/

\section{(cc) (i) Open Access}

\begin{abstract}
Food safety along with nutrition is an important issue in the present word. Only nutritionally safe food can ensure a healthy balanced diet to consumers. Dried fish is a popular processed fishery product not only in our country, but also in many countries of the world. It is a very good source of dietary protein, lipid and minerals necessary for a healthy body. The consumers of dried fish in national and international level are losing their interest to buy dried fish due to poor quality and safety of the products. Therefore, we reviewed the state of knowledge regarding the contamination level of dried fish by heavy metals, harmful pesticides, amount of lipid oxidation, and microbial quantity and quality from several districts in Bangladesh. The data reviewed in this article revealed that several dried fishes contaminated with excess amount of heavy metals $(\mathrm{Pb}, \mathrm{Cd}, \mathrm{Cr}$ etc.), pesticide residue (dichlorodiphenyltrichloroethane, heptachlor, endrin, aldrin, dieldrin), higher degree of lipid oxidation, excess amount of total plate count and presence of highly pathogenic E. coli, Salmonella sp. Vibrio sp. were found in few dried fish that may cause substantial human health hazard after consumption. The possible factors of these hazards are traditional drying, use of illegal pesticides with higher dose, lack of maintaining proper hygiene, sanitation, packaging, storage, distribution as well as water pollution. These findings will be helpful to develop an effective quality control and assurance program for producing safe dried fishery products for domestic consumption as well as earning foreign currency.
\end{abstract}

\section{Keywords}

Organochlorine Chemicals, Heavy Metals, Lipid Oxidation, Microorganisms, Dried Fish 


\section{Introduction}

Fish and fisheries are the intrinsic part of life of Bangladeshi people from ancient time and play a vital role in generating employment, nutrition, earning foreign currency and many aspects of the economy [1]. Drying is an effective and low-cost processing method of fish preservation by lowering the moisture level of fish body [2]. It has been practiced to preserve fish for longer periods in various parts of the world especially in Asian and African countries and it is very popular due to its simplicity and low-cost method and the dried fish develops characteristic texture and flavor [3]. It is estimated that about $20 \%$ of the local artisanal fish catch are sun-dried and consumed in the local market in Bangladesh [4]. Moreover, dried fish (commonly called as Shutki) acts as a protein source and plays a vital role in providing nutrition for the poor people of Bangladesh [5]. Generally, in developing country like Bangladesh drying of fish is practiced on the sand of the beach, on elevated bamboo rack and on the bamboo covering. The drying process of fish under the sun takes about 1 week depending on temperature, humidity and air velocity etc. [6].

In Bangladesh, proper hygiene and sanitation are not maintained during drying of fish; therefore, insect infestation, presence of dirt, filth and pesticide residue are very common problems with the dried fish products of Bangladesh [5] [7] [8]. The fish processors who are involved in drying, packaging and distribution of fish to the market are not well trained and also do not have proper knowledge of public health and sanitation [9] [10]. Generally, the dried fish are stored in a warehouse nearby the coastal town. Longer duration for drying can cause several spoilage and quality loss due to blowfly infestation, broken pieces, dirt and filth on the product. Some reports indicate 30\% - 40\% weight loss of dried fish due to insect infestation and dull weather [10] [11]. During monsoon season, the weather becomes humid that delays the drying process and dried fish also reabsorb moisture from the environment, which makes a suitable condition for beetle and mite infestation on the fish body [10] [12]. Another problem is most of the fishermen who are involved in fish drying process and do not dry fish properly for weight loss because they want to make more profit by selling dried fish in wet condition; thus, it reduces the quality of the final product and also accelerates the insect infestation [13] [14]. Moreover, fish processors usually use a mixture of organochlorine (dichlorodiphenyltrichloroethane (DDT) and heptachlor) insecticides to protect the dried fish from insect infestation [15] [16] [17]. Some studies also showed the presence of alarming pollutants like DDT and heptachlor in dried fish of Bangladesh [18]. Some fish processors from $\mathrm{Ku}$ akata of Patuakhali district have also used higher doses of DDT powder in the dried fish, though it is a banned chemical [19]. Insecticides are a great hazard for public health. The major problem of using insecticides in many Asian countries like Bangladesh is that they have no information about recommended dose and most of the cases; processors do not follow the instructions that are written on the insecticide label and sometimes labeling gives false information [10] [20]. 
Besides these things, the quality of dried fish is deteriorated due to the accumulation of heavy metal from the aquatic environment [21]. Moreover, improper processing and storage also enhanced lipid rancidity that produces off flavor, off odor and harmful hydro peroxide compounds [22] [23] that ultimately increase the microorganism growth in dried fish [24] [25]. All these problems make dried fish unsafe for human consumption which is associated with human health hazard. We know hazard means a substance of food that may cause adverse effects on human health. This review article focuses on chemical and microbiological hazards of dried fish in Bangladesh. This kind of information will be helpful for the protection of consumers' health.

\section{Chemical Hazards}

\subsection{Heavy Metals in Dried Fish}

Heavy metals are non-biodegradable materials which cause serious carcinogenic effects on animals and human body [26]. Fish and fishery products may be contaminated by heavy metals as fishes live in the aquatic environment. Reference [21] studied the level of heavy metal contamination in the dried fish found in Cox's Bazar local market. Comparatively higher amount of heavy metals was accumulated in Mola (Amblopharyngodon mola), Rupchanda (Stromateus chinensis) and Chhuri (Trichiurus lepturus) than other fish species (Loitta, Shundori, Fatra, Phasa). Iron ( $\mathrm{Fe}$ ) was found in greater concentrations compared to other heavy metals [21]. Also, reference [27] found more or less similar amount of cadmium, chromium and lead in the sun dried Loitta (Harpodon nehereus) and Churi (Trichiurus haumela), which is higher than the Maximum Allowable Limit of reference [26] [28] [29]. Besides, the excess amount of these three heavy metals $(\mathrm{Cd}, \mathrm{Cr}$ and $\mathrm{Pb})$ were also found in dried taki, tengra, shol and punti collected from the local market of Natore district of Bangladesh [30] (Table 1). Similarly, $\mathrm{Cd}, \mathrm{Cr}$ and $\mathrm{Pb}$ concentration in Silver pomfret (Stromateus cinereus) and Perch (Lates calcarifer) purchased from the local fish markets of Cox's Bazar exceeded the maximum allowable limit [31] (Table 1). Moreover, reference [32] investigated the heavy metal concentration in dried boal (Wallago attu) collected from Mymensingh local market. They observed that the Chromium (Cr) concentration was $0.068 \mathrm{ppm}$, which exceeds the acceptable limit for human consumption, according to reference [28].

These heavy metals are accumulated in fish and other aquatic organisms from aquatic environmental pollution due to enhanced urbanization, industrialization, population number and over exploitation of mother nature [33] [34] [35]. Most of the heavy metal elements are cumulative poisons, that is, those that cause injury to health through progressive and irreversible accumulation in the body as a result of ingestion of small amounts repeatedly [36]. Cadmium affects kidneys and causes symptoms of chronic toxicity, including impairment of kidney function, poor reproductive capacity, hypertension, tumors and hepatic dysfunction [37]. Excess exposure to $\mathrm{Pb}$ may cause nervous system damage, 
Md. G. Rasul et al.

Table 1. Concentration of different heavy metals in dried fish of Bangladesh.

\begin{tabular}{|c|c|c|c|c|c|c|c|}
\hline \multirow{2}{*}{ Fish species } & \multirow{2}{*}{ Location } & \multicolumn{5}{|c|}{ Concentrations (ppm) } & \multirow[t]{2}{*}{ Reference } \\
\hline & & $\mathrm{Cd}$ & $\mathrm{Cr}$ & $\mathrm{Pb}$ & $\mathrm{Fe}$ & $\mathrm{Cu}$ & \\
\hline \multirow[t]{3}{*}{ Loitta (Harpodon neherus) } & Cox’s Bazar & 0.029 & 0.323 & - & 9.384 & 0.1031 & \multirow{2}{*}{ [21] } \\
\hline & Saint Martin & 0.0226 & 0.311 & - & 12.967 & 0.057 & \\
\hline & Cox’s Bazar & 0.824 & 8.38 & 8.281 & - & 2.210 & [27] \\
\hline \multirow[t]{2}{*}{ Mola (Amblopharyngodon mola) } & Cox’s Bazar & 0.0179 & 0.3072 & - & 52.773 & 0.0473 & \multirow{2}{*}{ [21] } \\
\hline & Saint Martin & 0.0232 & 0.314 & - & 9.7269 & 0.0454 & \\
\hline \multirow[t]{2}{*}{ Gonia (Labeo gonius) } & Cox’s Bazar & 0.0545 & 0.3657 & - & 10.004 & 0.2632 & \multirow{2}{*}{ [21] } \\
\hline & Saint Martin & 0.0256 & 0.746 & - & 21.008 & 0.2092 & \\
\hline \multirow[t]{2}{*}{ Shundori (Nemipterus vigatus) } & Cox’s Bazar & 0.0209 & 0.3702 & 0.2571 & 18.926 & 0.185 & \multirow{2}{*}{ [21] } \\
\hline & Saint Martin & 0.0592 & 0.4872 & 0.2692 & 19.1961 & 0.229 & \\
\hline \multirow[t]{3}{*}{ Churi ( Trichiurus lepturus) } & Cox’s Bazar & 0.0156 & 0.5502 & $\mathrm{BDL}$ & 65.938 & 0.1925 & \multirow{2}{*}{ [21] } \\
\hline & Saint Martin & 0.0191 & 0.539 & 0.1243 & 20.526 & 0.3172 & \\
\hline & Cox’s Bazar & 0.485 & 6.969 & 5.465 & & 1.401 & [27] \\
\hline \multirow[t]{2}{*}{ Rupchanda (Stromateus chinensis) } & Cox’s Bazar & 0.0191 & 8.5352 & 0.0277 & 19.685 & 0.1571 & \multirow{2}{*}{ [21] } \\
\hline & Saint Martin & 0.0221 & 0.1743 & 0.4625 & 30.314 & 0.2278 & \\
\hline \multirow[t]{2}{*}{ Fatra } & Cox’s Bazar & 0.1428 & 0.163 & 0.0277 & 15.555 & 0.1664 & \multirow{2}{*}{ [21] } \\
\hline & Saint Martin & 0.1339 & 0.1968 & 0.397 & 16.477 & 0.5108 & \\
\hline \multirow[t]{2}{*}{ Phasa (Septipinna phasa) } & Cox’s Bazar & 0.0633 & 0.1788 & 0.0277 & 13.056 & 0.1981 & \multirow{2}{*}{ [21] } \\
\hline & Saint Martin & 0.1386 & 0.8445 & 0.4021 & 16.077 & 0.116 & \\
\hline Silver pomfret (Stromateus cinereus) & Cox’s Bazar & 0.68 & 5.85 & 8.43 & - & 1.15 & [31] \\
\hline Perch (Lates calcarifer) & Cox’s Bazar & 0.65 & 5.60 & 6.28 & - & 1.04 & [31] \\
\hline Boal (Wallago attu) & Mymensingh & 0.097 & 0.068 & - & - & - & [32] \\
\hline Taki (Channa punctatus) & Natore & 0.0192 & 0.91 & 1.288 & - & 3.03 & [30] \\
\hline Tengra (Mystus vitatus) & Natore & 0.0163 & 0.72 & 0.6088 & - & 23.6 & [30] \\
\hline Shol (Channa striatus) & Natore & 0.0179 & 0.99 & 0.9968 & - & 6.60 & [30] \\
\hline Punti (Puntius sophore) & Natore & 0.0149 & 1.47 & 1.60 & - & 6.12 & [30] \\
\hline Standard & & $0.1 \mathrm{ppm}$ & $0.05 \mathrm{ppm}$ & $0.1 \mathrm{ppm}$ & 15 ppm & $30 \mathrm{ppm}$ & \\
\hline Source & & [26] & {$[28]$} & [29] & {$[21]$} & {$[29]$} & \\
\hline
\end{tabular}

paralysis, and pain in the legs [38]. Moreover, $\mathrm{Cr}$ is also injurious to health. If eaten regularly with contaminated fish and fishery products, $\mathrm{Cr}$ cause irreversible problem in stomach, renal disease and overall health risk [31]. Many countries in the world are taking various types of mandatory and voluntary actions to prevent aquatic pollution by hazardous chemicals to ensure food safety, especially for aquatic food products. The food regulatory and health authority of some developed countries have taken serious measures and adopted a maximum allowable limit for hazardous substances by considering their effect on human health [32]. 


\subsection{Harmful Pesticide and Insecticides in Dried Fish}

Insect infestation is a major problem during fish drying [39]. Fish processors have usually taken various preventive measures to protect the dried fish from insect infestation [16]. Among them the most popular preventive measure is the use of hazardous chemical pesticides without considering the lethal effects of these pesticides on consumer body. DDT and Nogos are most commonly used in dried fish as pesticides to prevent insect infestation [5]. In another study, reference [15] found that DDT and Heptachlor are used in dried fish of Bangladesh as a mixture of organochlorine (Table 2). DDT is locally known as white powder. These chemical pesticides are effective to protect fish from insect infestation, but they are associated with human health hazard and also hazardous for the environment [12] [20].

In the last few years, application of a number of health hazard pesticides (e.g. dichloro-diphenyl-trichloroethane, heptachlor) has been exposed nakedly in the dried fish industries [16]. However, the maximum recommended limit (MRL) of DDT is $50 \mathrm{ppb}$ and the MRL of heptachlor, endrin, aldrin and dieldrin (Dirty Dozen) in food is $10 \mathrm{ppb}$ [40]. Exceeding this limit of these chemicals causes a long-term health effects and a variety of diseases to the consumers. Also, reference [15] screened DDT concentration ranges from 3.038 to $874.966 \mathrm{ppb}$ and heptachlor residue ranges from 0.682 to $5.464 \mathrm{ppb}$ in the dried Bombay duck (Harpodon nehereus), Ribbon fish (Trichiurus haumela) from 4 different places of Dhaka and Chattogram. It can be assumed from this study that a mixture of insecticides is still used in the dried fish of Bangladesh. In another study, the DDT and heptachlor concentration in dried Anhovy (Septipinna phasa) and Croaker (Johnius dussumieri) were $19.416 \mathrm{ppb}$ and $18.306 \mathrm{ppb}$, and $16.404 \mathrm{ppb}$ and $14.856 \mathrm{ppb}$, respectively [41], which exceeded the MRL (Table 2). Similarly, the excess amount of heptachlor was found in dried Chinese pomfret (Pampus chinensis) and Indian salmon (Polynemus indicas) [42] [43]. It was observed that heptachlor is a carcinogenic to human (B2) and it can pass to unborn baby from pregnant mother's through the placenta [44].

In another study, the mean concentration of DDT in dried Bombay Duck (Harpodon nehereus) collected from Borobazar and Reajuddin Bazar stations, Chinese Pomfret (Pampus chinensis) from Kalishpur and Reajuddin Bazar, Shrimp (Penaeus spp.) from Borobazar and Moilapara were ranged from 261.89 ppb and 874.35 ppb; $250.47 \mathrm{ppb}$ and $877.82 \mathrm{ppb} ; 161.67 \mathrm{ppb}$ and $589.97 \mathrm{ppb}$, respectively [18]. For ribbon fish (Lepturacanthus savala), the DDT residues were 141.43 and 253.68 ppb that detected from Reajuddin Bazar, Borobazar and Moilapara station, respectively, which were higher than the acceptable limit recommended by WHO. DDT concentration in the Ribbon fish (Trichiurus haumela), Bombay duck (Harpodon nehereus) and croaker (Johnius dussumieri) were ranged from 130.85 to $153.47 \mathrm{ppb}, 125.21$ to $181.4 \mathrm{ppb}$ and 119.86 to $208.65 \mathrm{ppb}$, respectively. The mean concentrations of DDT were found at a lower amount in Penaeus sp. than the other, which indicates that the concentrations of DDT in 
Table 2. Concentration of DDT and heptachlor in marine dried fish in different regions of Bangladesh.

\begin{tabular}{|c|c|c|c|c|}
\hline Fish species & Location & $\begin{array}{c}\text { DDT residue } \\
(\mathrm{ppb})\end{array}$ & $\begin{array}{l}\text { Heptachlor } \\
\text { residue (ppb) }\end{array}$ & Reference \\
\hline \multirow{7}{*}{$\begin{array}{c}\text { Ribbon fish } \\
\text { (Trichiurus haumela) }\end{array}$} & New Market, Dhaka & 149.430 & 1.710 & [15] \\
\hline & Karwan Bazaar, Dhaka & 131.611 & 1.937 & [15] \\
\hline & Asadgonj Bazaar, Chattogram & 140.398 & 2.306 & [15] \\
\hline & Asadgonj Bazaar, Chattogram & 137.535 & ND & [15] \\
\hline & New Market Bazar & 132.11 & ND & [45] \\
\hline & Asadgonj Bazar & 139.34 & ND & [45] \\
\hline & Teknaf Bazar & 134.28 & ND & [45] \\
\hline \multirow{3}{*}{$\begin{array}{c}\text { Ribbon fish } \\
\text { (Lepturacanthus savala) }\end{array}$} & Sayedpur & 755.032 & ND & {$[47]$} \\
\hline & Coxx's Bazar & 209.185 & ND & {$[47]$} \\
\hline & Reajuddin Bazar & 141.43 & ND & {$[18]$} \\
\hline \multirow{10}{*}{$\begin{array}{c}\text { Bombay duck (Harpodon } \\
\text { nehereus) }\end{array}$} & Karwan Bazaar, Dhaka & 182.333 & 1.762 & [15] \\
\hline & Asadgonj Bazaar, Chattogram & 874.966 & 5.464 & [15] \\
\hline & Asadgonj Bazaar, Chattogram & 61.918 & 2.283 & [15] \\
\hline & Sayedpur & 485.809 & ND & [47] \\
\hline & Cox’s Bazar & 262.185 & ND & {$[47]$} \\
\hline & Reajuddin Bazar & 874.35 & ND & [18] \\
\hline & Borobazar & 261.89 & ND & {$[18]$} \\
\hline & Teknaf & 145.75 & ND & [45] \\
\hline & Asadgonj Bazar & 181.14 & ND & [45] \\
\hline & New market Bazar & 168.36 & ND & [45] \\
\hline \multirow{3}{*}{$\begin{array}{l}\text { Chinese pomfret } \\
\text { (Pampus chinensis) }\end{array}$} & Karwan Bazar & ND & 54.753 & {$[42]$} \\
\hline & Khalispur & 250.47 & ND & [18] \\
\hline & Reajuddin Bazar & 877.82 & ND & [18] \\
\hline $\begin{array}{c}\text { Indian Salmon (Polynemus } \\
\text { indicas) }\end{array}$ & Asadgonj Bazar & 233.70 & 37.8 & {$[43]$} \\
\hline Anchovy (Septipinna phasa) & Karwan Bazar & 19.416 & 18.306 & [41] \\
\hline \multirow[t]{3}{*}{ Shrimp (Penaeus spp.) } & Cox's Bazar & 146.37 & ND & [45] \\
\hline & Moilapata & 585.97 & ND & [18] \\
\hline & Borobazar & 161.67 & $\mathrm{ND}$ & [18] \\
\hline \multirow[t]{2}{*}{ Perch (Lates calcarifer) } & Sayedpur & 298.165 & ND & {$[47]$} \\
\hline & Cox’s Bazar & 242.166 & ND & {$[47]$} \\
\hline \multirow{7}{*}{$\begin{array}{l}\text { Croaker (Johnius } \\
\text { dussumieri) }\end{array}$} & Karwan Bazar & 16.404 & 14.856 & [41] \\
\hline & Cox’s Bazar & 184.22 & ND & [45] \\
\hline & Teknaf & 119.86 & ND & [45] \\
\hline & Moheskhali & 133.52 & ND & [45] \\
\hline & New Market & 208.65 & ND & [45] \\
\hline & Asadgonj Bazar & 180.63 & ND & {$[45]$} \\
\hline & Reajuddin Bazar & 167.52 & ND & {$[45]$} \\
\hline
\end{tabular}

ND: Not determined; MRL of DDT is $50 \mathrm{ppb}$, MRL of heptachlor is $10 \mathrm{ppb}$. 
dried fish from Bangladesh were higher and may cause chronic disease and potential long-term risk to human health [45].

A significant amount of multiple pesticides (DDT, endrin, aldrin, dieldrin) have been found in various dried fishes such as tengra, taki, shol, chingri, prawn, kaski, chapila, gonia, mola and puti [20] [46] [47] [48] (Table 3 and Table 4). The presence of multiple pesticides in dried fish could be explained as a single pesticide used by dried fish producers and another might be used by the dried fish value chain vendors for long-term preservation [16] [20]. Besides, reference [49] reported that more than $60.19 \%$ fish and fisheries products contain pesticide residue. Moreover, contaminations of pesticide in fish and fisheries products varied geographically. DDT, Heptachlor, Diazinon, Chlorpyriphos, Acephate, Qunalphos, Carbaryl, etc. were abundant in Dhaka, Chattogram and Rajshahi divisions [49]. Also, reference [16] screened 92 dried fish samples obtained from eight districts of Bangladesh and found that 42 samples were contaminated with DDT, Dimethoate, Fenitrothion, Chlorpyrifos, Acephate and Diazinon residues, which are extremely hazardous for humans and the environment.

Dried fish contaminated with DDT is responsible for chronic health hazards as DDT is a slow poising substance and shows vertical transmission from generation to generation through breast milk [50]. It is the most concerning issue. Processors, exposed to DDT occupationally have an increased incidence of non-allergic

Table 3. Concentration of DDT in fresh water dried fish in different regions of Bangladesh.

\begin{tabular}{|c|c|c|c|}
\hline Fish species & Location & $\mathrm{DDT}$ residue (ppb) & Reference \\
\hline Tengra (Mystus vitatus) & Sayedpur & 370.461 & [47] \\
\hline \multirow[t]{2}{*}{ Punti (Puntius sophore) } & Sayedpur & 204.403 & [47] \\
\hline & Dhaka & 187.41 & {$[46]$} \\
\hline \multirow[t]{2}{*}{ Taki (Channa punctatus) } & Sayedpur & 420.191 & [47] \\
\hline & Cox’s Bazar & 111.495 & [47] \\
\hline \multirow[t]{3}{*}{ Shol (Channa striatus) } & Sayedpur & 1249.68 & [47] \\
\hline & Cox’s Bazar & 587.146 & [47] \\
\hline & Dhaka & 177.23 & [46] \\
\hline Boro Chingri (Macrobrachium rosenbergii) & Dhaka & 183.48 & [46] \\
\hline \multirow[t]{3}{*}{ Prawn (Leander styliferus) } & Sayedpur & 515.185 & [47] \\
\hline & Cox's Bazar & 161.739 & [47] \\
\hline & Dhaka & 332.38 & {$[46]$} \\
\hline Gonia (Labeo gonius) & Dhaka & 7968.26 & [46] \\
\hline Kaski (Corica soborna) & Dhaka & 808.68 & {$[46]$} \\
\hline Chapila (Gudusia chapra) & Dhaka & 665.72 & {$[46]$} \\
\hline Chanda (Chanda ranga) & Dhaka & 554.78 & {$[46]$} \\
\hline
\end{tabular}

MRL of DDT is $50 \mathrm{ppb}$. 
Table 4. Concentration of endrin, aldrin and dieldrin in fresh water dried fish in different regions of Bangladesh.

\begin{tabular}{ccccc}
\hline \multirow{2}{*}{ Fish species } & Location & Detected pesticide & $\begin{array}{c}\text { Pesticide residue } \\
(\mathrm{ppb})\end{array}$ & Reference \\
\hline Kaski (Corica soborna) & Rajshahi & 120 & {$[48]$} \\
& Dhaka & 105 & {$[48]$} \\
& Dinajpur & 90 & {$[48]$} \\
& Mymensingh & 120 & {$[48]$} \\
& Bogra & Endrin & 70 & {$[48]$} \\
& Chattogram & 60 & {$[48]$} \\
& Mymensingh & & 80 & {$[48]$} \\
& Bogura & & 90 & {$[48]$} \\
& Dinajpur & & 50 & {$[48]$} \\
Mola (Amblopharyngodon mola) & Bogura & & 120 & {$[48]$} \\
& Sylhet & & 828 & {$[20]$} \\
Puti (Puntius sophore) & Sylhet & Aldrin & $332-812$ & {$[20]$} \\
& Sylhet & Dieldrin & 762 & {$[20]$} \\
\hline
\end{tabular}

MRL of Endrin, aldrin and dieldrin is $10 \mathrm{ppb}$.

asthma [51] and have direct links with diabetes [52], cancer [53]. A number of studies have argued that the accumulation of DDT in human body before puberty increases the risk of breast cancer for the women [54]. At present, importing as well as producing the "Dirty Dozen" pesticides is prohibited in Bangladesh. Now a day, there is no legal use of any persistent organochlorine pesticides in Bangladesh, however, some old stocks may be available and some may be available through other unknown sources [20] [55].

\subsection{Lipid Oxidation in Dried Fish}

Fish lipids containing polyunsaturated fatty acids are highly unstable and susceptible to reaction with atmospheric oxygen and produce hydroperoxide compounds and free radicals cause off flavor and off odor in dried fish. The higher amount of hydroperoxide compounds and free radicals indicate the poor quality of a food product [56] [57]. Table 5 shows rate of lipid oxidation in dried fishes available in Bangladesh. The peroxide values of the traditionally dried 8 marine fish samples ranged between 46.80 and $82.70 \mathrm{meq} / \mathrm{Kg}$ oil [58]. Almost all values are above the acceptable limit indicating whole marine dried fish can be considered to be spoiled for most uses. More or less similar findings have been reported in the cases of dried tengra [22] and kholisa [23] and sun dried puti, chapila, taki [59]. Moreover, the excess amount of acid value was also found in dried kholisa, punti, chapila and taki [23] [59]. In general, the rate of oxidation increases with the increasing temperature. Other factors may be relative humidity of environment and absorbing moisture from atmosphere. The increased peroxide 
Table 5. Peroxide value and acid values of some dried fish in Bangladesh.

\begin{tabular}{|c|c|c|c|c|}
\hline Dried fish & Location \& Storage condition & $\begin{array}{l}\text { Peroxide value } \\
\text { (meq/Kg of lipid) }\end{array}$ & $\begin{array}{l}\text { Acid value (mg } \\
\mathrm{KOH} / \mathrm{g} \text { of lipid) }\end{array}$ & Reference \\
\hline Tengra (Mystus vitatus) & Gazipur and stored in room temperature at 90 days & 25.35 & 19.59 & [22] \\
\hline Kholisa (Trichogaster fasciata) & Gazipur and stored in room temperature at 90 days & 27.87 & 22.25 & [23] \\
\hline Punti (Puntius sophore) & Dhaka city & 36 & 20.83 & [59] \\
\hline Chapila (Gudusia chapra) & Dhaka city & 32.6 & 22.25 & [59] \\
\hline Taki (Channa puntatus) & Dhaka city & 33.09 & 25.13 & [59] \\
\hline Chinese pomfret (Stromateus chinensis) & $\begin{array}{l}\text { Cox's Bazar and packed in pyrogen-free } \\
\text { polyethylene bag }\end{array}$ & 48.67 & - & [58] \\
\hline Silver pomfret (Stromateus cinereus) & & 72.50 & - & [58] \\
\hline Riksha fish (Ricksha sp.) & & 54.40 & - & [58] \\
\hline Silver jew fish (Johinus argentatus) & & 72.50 & - & [58] \\
\hline Ribbon fish (Trichiurus haumela) & & 74.60 & - & [58] \\
\hline Bombay duck (Harpodon neherus) & & 72.70 & - & [58] \\
\hline Red snapper (Lutjanus johnii) & & 46.80 & - & [58] \\
\hline Shrimp (Penaeus sp.) & & 82.70 & - & [58] \\
\hline Standard & & 20 & 20 & [36] \\
\hline
\end{tabular}

and acid value in the dried products are susceptible to rapid oxidation during processing, drying and storage under abused influencing conditions. The abused influencing conditions include inappropriate packaging causing off flavor and off odor [22] [23] [60] [61] [62] which reduce the product value to the consumers. Oxidized dried fish products are not safe for human consumption [63]. The lipid oxidation primary products in fish reduce its protein digestibility [64] and formation of secondary oxidation products can cause aging, membrane injury, cardiovascular diseases, atherosclerosis and tumor growth [65] [66].

\section{Microbiological Hazards}

Now a day, consumers are very much concerned about the quality of dried fish products. They consider not only chemical contaminants, spoilage but also infestation by flies and microorganisms while buying dried fish. Various microorganisms adversely affect the quality of dried fishery products due to traditional drying, storage and distribution [23] [67]. The presence of the pathogenic microbial loads in dried fishes is getting importance in the safety and quality aspects of the dried fishes [68]. Particularly, besides pathogenic bacteria, some pathogenic molds have been found as a significant amount in dried food [69]. The incidence of Salmonella sp. in various dried fishes directly indicated the maintenance of poor hygienic condition during drying [67].

The total viable count of bacteria, 7 log CFU/g is the upper acceptable limit for fresh and frozen fish and cold-smoked fish species [70] and beyond this lim- 
it, the product is not safe for the consumer. The amount of total plate count in ten indigenous dried fish varied between 7.50 to $8.56 \log$ CFU/g [25] (Table 6). More or less similar findings were observed in the cases of dried kholisa [23], dried tengra [22] and dried taki [71]. Besides, the bacterial load of traditionally dried small indigenous species products ranged from $8.156 \log$ CFU/g to 8.460 $\log$ CFU/g [72]. During improper packaging, storage and exposed condition in the retail market, dried products absorb a considerable amount of moisture because humidity enhances the microbial load [22] [71]. Moreover, spores of bacteria may not be destroyed at the time of drying because of an inappropriate or low drying temperature.

In Table 7, E. coli, Salmonella sp. were found in sun dried Mastacembelus armatus [24], in dried Puntius sophore [20] [73] and in Puntius chola, Brama brama, Penaeus monodon [74]. Besides, Vibrio sp. were identified in dried Puntius sophore [20] [73] and dried Brama brama [74]. E. coli, Salmonella, Shigella, $S$. aureus are highly pathogenic bacteria which indicates the fecal contamination of water from where fish were harvested and their presence in food can cause food poisoning, food infection to consumer [75]. Seafood products harvested from contaminated waters, which have been improperly preserved after harvesting, are known to play an important role in infections by Vibrio sp. [76]. It can cause diarrhea, headache, vomiting, nausea, abdominal cramps, and low fever to consumers [77]. Besides, total staphylococcal count (TSC) in dried churi, chingri, punti, mola, challa and chapila collected from Chattogram and Mymensingh district were 86.33, 31.67, 32.33, 61.00, 53.00 and 53.67 respectively [67]. It has been reported that Staphylococcus sp. was found in sun dried Brama

Table 6. Total plate count (log CFU/g) of various dried fish in Bangladesh.

\begin{tabular}{cccc}
\hline Fish species & Location & Total plate count (log CFU/g) & Reference \\
\hline Mola (Amblypharyngodon mola) & Dhaka city & 8.26 & {$[25]$} \\
Puti (Puntius sophore) & Dhaka city & 7.50 & {$[25]$} \\
& Sylhet & 5.2 & {$[20]$} \\
Batasi (Pseudeutropius atherinoides) & Dhaka city & 8.49 & {$[25]$} \\
Tengra (Mystus vitatus) & Dhaka city & 8.24 & {$[25]$} \\
Chapila (Gudusia chapra) & Gazipur & 8.88 & {$[22]$} \\
Katchki (Corica soborna) & Dhaka city & 8.56 & {$[25]$} \\
Churi (Trichiurus lepturus) & Dhaka city & 8.56 & {$[25]$} \\
Taki (Channa punctatus) & Dhaka city & 7.61 & {$[25]$} \\
& Natore & 8.29 & {$[25]$} \\
Loita (Harpadon nehereus) & Dhaka city & 7.56 & {$[71]$} \\
Chanda (Chanda ranga) & Dhaka city & 8.39 & {$[25]$} \\
Kholisa (Trichogaster fasiata) & Gazipur & 7.52 & {$[25]$} \\
\hline
\end{tabular}


Table 7. Pathogenic bacteria in some dried fish

\begin{tabular}{|c|c|c|c|c|c|c|}
\hline Fish species & $\begin{array}{l}\text { Sample } \\
\text { source }\end{array}$ & $\begin{array}{c}\text { Total } \\
\text { sample } \\
\text { tested }\end{array}$ & $\begin{array}{c}\text { E. coli } \\
(\%)\end{array}$ & $\begin{array}{c}\text { Salmonella } \\
(\%)\end{array}$ & $\begin{array}{c}\text { Vibrio } \\
(\%)\end{array}$ & Reference \\
\hline \multirow[t]{2}{*}{ Mastacembelus armatus } & Bondor Bazar, Sylhet & 25 & 100 & 80 & - & [24] \\
\hline & Lamagaji, Sylhet & 25 & 100 & 60 & - & {$[24]$} \\
\hline \multirow[t]{5}{*}{ Puntius sophore } & Mahtabpur, Sylhet & 25 & 100 & 32 & 28 & [73] \\
\hline & Tuker Bazar, Sylhet & 25 & 100 & 36 & 24 & [73] \\
\hline & Local Market, Sylhet & 25 & 100 & 44 & 40 & [73] \\
\hline & Producer & 15 & 100 & 13.3 & 0 & [20] \\
\hline & Retailer & 15 & 100 & 20 & 13.3 & [20] \\
\hline Puntius chola & Kawran Bazar, Dhaka & 5 & 100 & 100 & - & {$[74]$} \\
\hline Amblypharyngodon mola & & 5 & 100 & - & - & [74] \\
\hline Brama brama & & 5 & 100 & 100 & 100 & {$[74]$} \\
\hline Harpodon neherreus & & 5 & 100 & - & - & {$[74]$} \\
\hline Penaeus monodon & & 5 & 100 & 100 & - & [74] \\
\hline
\end{tabular}

brama and Penaeus mondon, and Pseudomonas sp. was also isolated from dried Brama brama, Puntius chola and Amblyphryngogon mola collected from retail market of Kawran Bazar, Dhaka [74]. Monitoring of these microorganisms has been suggested as a measure of fish quality.

\section{Conclusions and Recommendations}

This review provides important information on heavy metal, organochlorine chemicals and pesticides, rate of lipid oxidation and microbial contamination of some dried fish samples collected from local markets, retail market and producer of Coxs Bazar, Chattogram, Dhaka, Gazipur, Sylhet, Khulna, Mymensingh, Bogura, Natore, Rajshahi, Dinajpur and Nilphamari district. The amount of contaminants and hazards detected by different researchers is alarming for Bangladesh and can be used as basic information to risk assessment of these dried fish to consumers and will help to make fruitful policy. Considering the above facts, several recommendations can be made to eradicate these hazards from dried fishery products in Bangladesh:

1) Develop safe and economical methods of drying, processing, packaging, storage, distribution and heavy metal decontamination strategies of dried fish products;

2) Provide awareness of fish processors and retailers about public health and sanitation practice and about the harmful role of various insecticides;

3) Provide necessary training to ensure good quality dried fish through improved, cost-effective and safe drying, packaging and storage method;

4) The processor should dry the fishes appropriately and pack properly so that the fish cannot reabsorb moisture in monsoon; 
5) Since organochlorine synthetic chemicals could cause danger to human health, these insecticides have been strictly banned in various countries (1970 in Sweden; 1971 in Japan; 1972 in USA). Therefore, the government of Bangladesh should implement and strictly enforce updated pesticide legislation and policies in fishery products;

6) Presence of heavy metal in aquatic environment and water pollution affects the aquatic ecosystem; it should be brought under continuous monitoring;

7) Enforce mandatory and voluntary actions to prevent aquatic pollution by hazardous chemicals etc.

\section{Conflicts of Interest}

The authors declare no conflicts of interest regarding the publication of this paper.

\section{References}

[1] Alam, M.F. (2002) Socioeconomic Aspects of Carp Production and Consumption in Bangladesh. In: Penman, D.J., Hussain, M.G., McAndrew, B.J. and Mazid, M.A., Eds., Proceedings of a Workshop on Genetic Management and Improvement Strategies for Exotic Carps in Asia, Bangladesh Fisheries Research Institute, Mymensingh, 83-93.

[2] Rasul, M.G., Majumdar, B.C., Afrin, F., Bapary, M.A.J. and Shah, A.K.M.A. (2018) Biochemical, Microbiological, and Sensory Properties of Dried Silver Carp ( $\mathrm{Hy}$ pophthalmichthys molitrix) Influenced by Various Drying Methods. Fishes, 3, 25. https://doi.org/10.3390/fishes3030025

[3] Balachandran, K.K. (2001) Post-Harvest Technology of Fish and Products, Daya Publishing House, Delhi, 77.

[4] Mazid, M.A. and Kamal, M. (2005) Development of Low-Cost Solar Dryer for the Production of Improved Quality Dried Fish. Final Report. BFRI, Marine Fisheries \& Technology Station and Bangladesh Agricultural University, Mymensingh, 65.

[5] Nowsad, A.K.M.A. (2007) Participatory Training of Trainers: A New Approach Applied in Fish Processing, Bengal Com-Print, 68/5, Dhaka, 151-191.

[6] Reza, M.S., Bapary, M.A.J., Islam, M.N. and Kamal, M. (2009) Optimization of Marine Fish Drying Using Solar Tunnel Dryer. Journal of Food Processing and Preservation, 33, 47-59. https://doi.org/10.1111/j.1745-4549.2008.00236.x

[7] Nowsad, A.K.M.A. (2005) Low-Cost Fish Processing in Costal Bangladesh. BGD/97/017, Field Doc: 5/2005. FAO, 88 p.

[8] Hasan, M.M., Rasul, M.G., Ferdausi, H.J., Trina, B.D., Sayeed, A., Shah, A.K.M.A. and Bapary, M.A.J. (2016) Comparison of Organoleptic and Chemical Characteristics of Some Traditional and Improved Dried Fish Products. Research Journal of Animal, Veterinary and Fishery Sciences, 4, 1-6.

[9] Hasan, M.M., Rasul, M.G., Ferdausi, H.J., Hossain, M.M., Shah, A.K.M.A. and Bapary, M.A.J. (2016) Present Status of Dried Fish Markets in Sylhet of Bangladesh. Progressive Agriculture, 27, 235-241. https://doi.org/10.3329/pa.v27i2.29336

[10] Paul, P.C., Reza, M.S., Islam, M.N. and Kamal, M. (2018a) A Review on Dried Fish Processing and Marketing in the Coastal Region of Bangladesh. Research in Agriculture Livestock and Fisheries, 5, 381-390. https://doi.org/10.3329/ralf.v5i3.39587

[11] Hollick, J.C. (1999) Commercial Scale Solar Drying. Renewable Energy, 16, 714-719. 
https://doi.org/10.1016/S0960-1481(98)00258-4

[12] Reza, M.S., Bapary, M.A.J., Azimuddin, K.M., Nurullah, M. and Kamal, M. (2005) Studies on the Traditional Drying Activities of Commercially Important Marine Fishes of Bangladesh. Pakistan Journal of Biological Sciences, 8, 1303-1310. https://doi.org/10.3923/pjbs.2005.1303.1310

[13] Islam, A.T.M.F., Islam, M.H., Hossain, T., Yasmin, M., Majumder, M.Z.R., Begum, M. and Saifullah, A.S.M. (2014) Evaluation of Fly Population Infesting Dried Fishes at Sonadia Island, Cox's Bazar as a prerequisite for the Practical Application of Sterile Insect Technique (SIT). Nuclear Science and Applications, 23, 1-7.

[14] Yousuf, M. (2019) Dried Fish Still Laced with Toxins. The Daily Star, Bangladesh. https://www.thedailystar.net/backpage/news/dried-fish-still-laced-toxins-1693828

[15] Bhuiyan, M.N.H., Bhuiyan, H.R., Rahim, M., Ahmed, K., Haque, K.M.F., Hassan, M.T. and Bhuiyan, M.N.I. (2008) Screening of Organochlorine Insecticides (DDT and Heptachlor) in Dry Fish Available in Bangladesh. Bangladesh Journal of Pharmacology, 3, 114-120. https://doi.org/10.3329/bjp.v3i2.997

[16] Hossain, E. (2018) Pesticide-Treated Dried Fish Exposes Consumers to Serious Health Risks in Bangladesh. Newage Bangladesh.

http://www.newagebd.net/article/50554/pesticide-treated-dried-fish-exposes-consu mers-to-serious-health-risks-in-bangladesh

[17] Mansur, M.A., Uddin, M.N., Haider, M.N., Mia, M.M. and Kimura, D. (2019) Use of Pesticide, Harmful Chemicals, Antibiotic during Sun-Drying of Fish-Safe or Dangerous for Consumer's Health. Oceanography and Fisheries, 10, 1-3. https://doi.org/10.19080/OFOAJ.2019.10.555779

[18] Hasan, M.N., Islam, H.M.R., Akter, R., Mahmud, Y., Ahmed, K.K.U. and Siddiquee, S. (2014) Determination of Dichlorodiphenyltrichloroethane Residues Levels in Commercial Marine Dry Fish from Different Regions of Bangladesh. Annual Research Review in Biology, 4, 2722-2729. https://doi.org/10.9734/ARRB/2014/9043

[19] Barua, S. (2007) Escaping from Organic Chemical Pollutants. The New Nation. Internet Edition. http://nation.ittefaq.com/rss.xm

[20] Hussain, M.A., Kabir, M.L., Sayeed, M.A., Elahi, A.T.M.M.E., Ahmed, M.S. and Islam, M.J. (2018) Organochlorine Pesticide Residues and Microbiological Quality Assessment of Dried Barb, Puntius sophore, from the Northeastern Part of Bangladesh. Fishes, 3, 44. https://doi.org/10.3390/fishes3040044

[21] Akter, S., Billah, M.B., Sarkar, S., Fardous, Z., Aktar, Z., Rahman, M.A. and Chowdhury, M.A.Z. (2019) Environmental Contamination of Heavy Metals in Some dried Fish of Coastal Regions of Bangladesh. Bangladesh Journal of Zoology, 47, 293-304. https://doi.org/10.3329/bjz.v47i2.44340

[22] Majumdar, B.C., Afrin, F., Rasul, M.G., Shaha, D.C. and Shah, A.K.M.A. (2018) Changes in Physicochemical, Microbiological, and Sensory Properties of Sun-Dried Mystus vittatus During Storage at Ambient Temperature. Fishes, 3, 32. https://doi.org/10.3390/fishes3030032

[23] Rasul, M.G., Majumdar, B.C., Afrin, F., Jahan, M., Chunhong, Y. and Shah, A.K.M. A. (2019) Changes in Physico-Chemical, Microbiological and Sensory Properties of Sun-Dried Trichogaster fasciata during Storage. Turkish Journal of Agriculture-Food Science and Technology, 7, 1568-1574. https://doi.org/10.24925/turjaf.v7i10.1568-1574.2589

[24] Aktar, T., Sayeed, M.A., Rasul, M.G., Kashem, M.A. and Paul, A.K. (2018) Evaluation of Microbiological Quality of Dried Baim (Mastacembelus armatus) in Bangladesh. Archives in Agriculture and Environmental Science, 3, 344-353. 
https://doi.org/10.26832/24566632.2018.030403

[25] Rana, M.M., Chakraborty, S.C. and Saeid, A. (2020) Comparative Studies of Nutritional, Microbial and Organoleptic Properties of Different Indigenous Dried Fish from Local Market in Bangladesh. Advanced Journal of Chemistry-Section A, 3, 318-328. https://doi.org/10.33945/SAMI/AJCA.2020.3.9

[26] European Commission (2008) Commission Regulation (EC) No. 629/2008 of 2 July 2008 Amending Regulation (EC) No. 1881/2006 Setting Maximum Levels for Certain Contaminants in Foodstuffs Official J European Union 173/6-9.

[27] Jamil, M.G., Hossain, M., Mia, M.M., Mansur, M.A. and Uga, S. (2017) Studies on the Proximate Composition, Quality and Heavy Metal Concentration of Sundried Bombay Duck and Sun-Dried Ribbon Fish of Cox's Bazar District of Bangladesh. Journal of Environmental Science and Natural Resources, 10, 55-60. https://doi.org/10.3329/jesnr.v10i1.34694

[28] European Commission (2006) Commission Regulation (EC) No. 1881/2006 of the European Parliament and the Council of 19 December 2006 Setting Maximum Levels for Certain Contaminants in Foodstuffs. Off. J. Eur. Communities L, 364.

[29] FAO. (2010) Trace Metals in Environments. http://www.fao.org/trace_metals.html

[30] Flowra, F.A., Bayezid, M.A., Alam, M.M., Hussain, M.A. and Jahan, S.N. (2017) Safety Aspects: An Assessment of Heavy Metals in Dried Fishes of Chalan beel. Journal of Agricultural Engineering and Food Technology, 4, 82-86.

[31] Hossain, M.N., Jamil, M.G.M., Mia, M.M., Uddin, M.N. and Mansur, M.A. (2017) Studies on the Proximate Composition, Quality and Heavy Metal Concentration of Two Sun Dried Marine Fish (Sun Dried Silver Pomfret and Sun Dried Perch) of Cox's Bazar District of Bangladesh. Journal of Environmental Science and Natural resources, 10, 25-32. https://doi.org/10.3329/jesnr.v10i1.34690

[32] Mansur, M.A., Rahman, S., Khan, M.N.A., Reza, M.S., Kamrunnahar and Uga, S. (2013) Study on the Quality and Safety Aspect of Three Sun-Dried Fish. African Journal of Agricultural Research, 8, 5149-5155.

[33] Rahman, M.S., Molla, A.H. and Arafat, S.M.Y. (2010) Status of Pollution around Dhaka Export Processing Zone and Its Impact on Bangshi River Water, Bangladesh. Journal of Nature Science and Sustainable Technology, 4, 91-110.

[34] Saha, N. and Zaman, M.R. (2011) Concentration of Selected Toxic Metals in Groundwater and Some Cereals Grown in Shibganj Area of Chapai Nawabganj, Rajshahi, Bangladesh. Current Science, 1010, 427-431.

[35] Rahman, M. S., Molla, A.H., Saha, N. and Rahman, A. (2012) Study of Heavy Metal Levels and Risk Assessment in Some Edible Fishes from Bangshi River, Savar, Dhaka, Bangladesh. Food Chemistry, 134, 1847-1854. https://doi.org/10.1016/j.foodchem.2012.03.099

[36] Connell, J.J. (1995) Control of Fish Quality. 4th Edition, Fishing News Books, Oxford.

[37] Waalkes, M.P. (2000) Cadmium Carcinogenesis in Review. Journal of Inorganic Biochemistry, 79, 241-244. https://doi.org/10.1016/S0162-0134(00)00009-X

[38] Nolan, K. (2003) Copper Toxicity Syndrome. Journal of Orthomolecular Psychiatry, $12,270-282$.

[39] Flowra, F.A., Tumpa, A.S. and Islam, M.T. (2013) Study on the Insect Infestation of Dry Fishes at Singra. Journal of Asiatic Society of Bangladesh Science, 39, 273-277. https://doi.org/10.3329/jasbs.v39i2.17868

[40] WHO (2005) The WHO Recommended Classification of Pesticides by Hazard. British 
Journal of Psychiatrist, 187, 583-584.

[41] Bhuiyan, M.N.H., Bhuiyan, H.R, Ahmed, K., Dawlatana, M., Haque, K.M.F., Rahim, M. and Bhuiyan, M.N.I. (2009) Organochlorine Insecticides (DDT and Heptachlor) in Dry Fish: Traditional Washing and Cooking, Effect on Dietary Intake. Bangladesh Journal of Pharmacology, 4, 46-50. https://doi.org/10.3329/bjp.v4i1.1051

[42] Bhuiyan, M.N.H., Dawlatana, M., Bhuiyan, H.R., Lucky, F.A., Saha, B.K. and Bhuiyan, M.N.I. (2009) Quality Assessment of Dry Fishes of Bangladesh with the Special Emphasis on Harmful Additives. Bangladesh Journal of Scientific and Industrial Research, 44, 311-318. https://doi.org/10.3329/bjsir.v44i3.4404

[43] Bhuiyan, N.H., Bhuiyan, H.R., Ahmed, K., Nath, K.K., Hassan, T. and Bhuiyan, N.I. (2009b) Organochlorine Insecticides (DDT and Heptachlor) in Dry Fish Available in Bangladesh: Seasonal Trends and Species Variability. Journal of Chilean Chemical Society, 54, 278-281. https://doi.org/10.4067/S0717-97072009000300016

[44] LDWG (Lower Duwamish Waterway Group) (2007) LDW RI: Baseline HHRA Attachment 4. Toxicological Profiles for Chemicals of Potential Concern. p. 39.

[45] Siddique, M.A.M. and Aktar, M. (2012) Detection of Health Hazard Insecticide Dichlorodiphenyltrichloroethane (DDT) in Some Common Marine Dry Fish Samples from Bangladesh. Health, 4, 185-189. https://doi.org/10.4236/health.2012.44027

[46] Chowdhury, M.A.Z., Amin-ud-Din, M., Malek, M.A. and Zaman, M.A. (2010) DDT Residue and Its Metabolites in Dried Fishes of Dhaka City Markets. Soil \& Environment, 29, 117-121.

[47] Hasan, M.N., Islam, H.M.R., Ahmed, K.K.U., Mahmud, Y. and Siddiqee, S. (2013) Screening and Quantification of Dichlorodiphenyltrichloroethane (DDT) and Dichlorovos in Selected Dry Fish Species of Bangladesh by GC-ECD Detector. International Journal of Scientific Research and Management, 1, 352-353.

[48] Begum, A., Ahmed, S. and Alam, S.N. (2017) Detection, Quantification and Decontamination of Pesticide Residues in Dry Fish. International Journal of Biosciences, 10, 246-252.

[49] Ali, M.M. (2016) Chemical Contaminants in Selected Fish, Fisheries Products and Important Foodstuffs of Bangladesh. Ph.D. Thesis. Department of Fisheries, Faculty of Biological Sciences, University of Dhaka, Bangladesh. 5 p.

[50] Solmon, G. and Weiss, P. (2001) Healthy Milk, Healthy Baby. Natural Resources Defense Council, New York.

[51] Brow, AJ. (2007) Pesticide Exposure Linked to Asthma. Scientific American, 162, 890897.

[52] Jones, O.A., Maguire, M.L. and Griffin, J.L. (2008) Environmental Pollution and Diabetes: A Neglected Association. The Lancet, 371, 287-288. https://doi.org/10.1016/S0140-6736(08)60147-6

[53] Rogan, W.J. and Chen, A. (2005) Health Risks and Benefits of Bis(4-chlorophenyl)-1, 1, 1trichloroethane (DDT). The Lancet, 366, 763-773. https://doi.org/10.1016/S0140-6736(05)67182-6

[54] Clapp, R.W., Jacobs, M.M. and Loechler, E.L. (2008) Environmental and Occupational Causes of Cancer: New Evidence 2005-2007. Reviews on Environmental Health, 23, 1-37. https://doi.org/10.1515/REVEH.2008.23.1.1

[55] ESDO (2005) Country Situation Report on Persistent Organic Pollutants in Bangladesh Environment and Social Development Organization. In: International POPS Elimination Project, Environment and Social Development Organization-ESDO, Dhaka, 1-33. 
[56] Maqsood, S., Benjakul, S. and Kamal-Eldin, A. (2012) Haemoglobin-Mediated Lipid Oxidation in the Fish Muscle: A Review. Trends Food Science and Technology, 28, 33-43. https://doi.org/10.1016/j.tifs.2012.06.009

[57] Mbunda, A.E. (2013) The Quality Changes in Smoked and Dried Fresh Water Sardine (Rastrineobola argentea) and Marine Pelagic Fish (Caplin) as Influenced by Processing Methods. [Final Project] http://www.unuftp.is/static/fellows/document/arnold12prf.pdf

[58] Paul, P.C., Reza, M.S., Islam, M.N. and Kamal, M. (2018) Quality Assessment of Traditionally Dried Marine Fish of Bangladesh. Asian Food Science Journal, 5, 1-11. https://doi.org/10.9734/AFSJ/2018/44406

[59] Majumdar, B.C. (2017) Comparison of the Changes in Nutritional Quality of Three Important Small Indigenous Fish Species in Bangladesh Stored at Room Temperature (27-31 $\left.{ }^{\circ} \mathrm{C}\right)$ : A Review. Journal of Animal Research and Nutrition, 2, 1-7. https://doi.org/10.21767/2572-5459.100035

[60] Toyomizu, M., Hanaoka, K. and Yamaguchi, K. (1981) Effect of Release of Free Fatty Acids by Enzymatic Hydrolysis of Phospholipids on Lipid Oxidation during Storage of Fish Muscle at $-5^{\circ}$ C. Bulletin of Japanese Society for Science of Fish, 47, 605-610. https://doi.org/10.2331/suisan.47.615

[61] Ramanathan, L. and Das, N.P. (1992) Studies on the Control of Lipid Oxidation in Ground Fish by Some Polyphenolic Natural Products. Journal of Agriculture and Food Chemistry, 40, 17-21. https://doi.org/10.1021/jf00013a004

[62] Alasalvar, C., Taylor, A.K.D. and Shahidi, F. (2005) Comparison of Volatiles of Cultured and Wild Sea Bream (Sparus aurata) during Storage in Ice by Dynamic Headspace Analysis/Gas Chromatography-Mass Spectrometry. Journal of Agriculture and Food Chemistry, 53, 2616-2622. https://doi.org/10.1021/jf0483826

[63] Shah, A.K.M.A., Tokunaga, C., Kurihara, H. and Takahashi, K. (2009) Changes in Lipids and Their Contribution to the Taste of Migaki-Nishin (Dried Herring Fillet) during Drying. Food Chemistry, 115, 1011-1018. https://doi.org/10.1016/j.foodchem.2009.01.023

[64] Boler, D.D., Fernandez-Duenas, D.M., Kutzler, L.W., Zhao, J., Harrell, R.J., Campion, D.R., Mc Keith, F.K., Killefer, J. and Dilger, A.C. (2012) Effects of Oxidized Coin Oil and a Synthetic Antioxidant Blend on Performance, Oxidative Status of Tissues and Fresh Meat Quality in Finishing Barrows. Journal of Animal Science, 90, 5159-5169. https://doi.org/10.2527/jas.2012-5266

[65] Suja, K.P., Abraham, J.T., Thamizh, S.N., Jayalekshmy, A. and Arumughan, C. (2004) Antioxidant Efficacy of Sesame Cake Extract in Vegetable Oil Protection. Food Chemistry, 84, 393-400. https://doi.org/10.1016/S0308-8146(03)00248-6

[66] Cho, S.P. (2005) Stability and Quality of Fish Oil during Typical Domestic Application. Project. Wonsan University of Fisheries, Wonsan.

[67] Sultana, N., Siddique, M.P., Farhana, Z., Dina, M.A. and Uddin, M.I. (2010) Isolation and Identification of Bacteria from Dried Fishes Collected from Different Areas of Bangladesh. International Journal Bioresource Stress Management, 2, 1-5.

[68] Patterson, J. and Ranjitha, G. (2009) Qualities of Commercially and Experimentally Sun Dried Fin Fish, Scomberoides tol. African Journal of Food Science, 3, 299-302.

[69] Hyun, J.E., Kim, J.H., Choi, Y.S., Kim, E.M., Kim, C. and Lee, S.Y. (2018) Evaluation of Microbial Quality of Dried Foods Stored at Different Relative Humidity and Temperature, and Effect of Packaging Methods. Journal of Food Safety, 38, e12433. https://doi.org/10.1111/jfs.12433

[70] ICMSF (International Commission on Microbiological Specifications for Foods) 
(1986) Sampling Plans for Fish and Shellfish. In: Microorganisms in Foods. Sampling for Microbiological Analysis. Principles and Scientific Applications, Vol. 2, 2nd Edition, University of Toronto Press, Toronto, 181-196.

[71] Islam, M.T., Ahmed, S., Sultana, M.A., Tumpa, A.S. and Flowra, F.A. (2013) Nutritional and Food Quality Assessment of Dried Fishes in Singra upazila under Natore District of Bangladesh. Trends in Fisheries Research, 2, 2319-4758.

[72] Hasan, M.M, Shikha, F.H., Hossain, M.I., Kamal, M., Islam, M.N. and Wahab, M.A. (2006) Quality Assessments of Traditional, Rotary and Solar Tunnel Dried Small Indigenous Fish Products. Bangladesh Journal of Fisheries Research, 10, 73-84.

[73] Hussain, M.A., Sayeed, M.A., Kabir, M.L., Sumon, T.A., Himu, S.D. and Sumon, M.A.A. (2016) Determination of Microbiological Quality of Dried Jat Punti (Puntius sophore) Collected from Sylhet District, Bangladesh. International Journal of Natural and Social Sciences, 3, 72-79.

[74] Nur, I.T., Ghosh, B.K. and Acharjee, M. (2020) Comparative Microbiological Analysis of Raw Fishes and Sun Dried Fishes Collected from Kawran Bazar in Dhaka City, Bangladesh. Food Research, 4, 846-851.

[75] Pal, M. (2010) Fish hygiene. MSc Lecture Notes. Addis Ababa University, Faculty of Veterinary Medicine, Debre Zeit, 1-11.

[76] Baffone, W., Pianetti, A., Bruscolini, F., Barbieri, D. and Citterio, B. (2000) Occurrence and Expression of Virulence Related Properties of Vibrio Species Isolated from Widely Consumed Seafood Products. International Journal of Food Microbiology, 54, 9-18. https://doi.org/10.1016/S0168-1605(99)00189-0

[77] Pal, M. (2007) Zoonoses. 2nd Edition, Satyam Publishers, Jaipur. 